\title{
Feeding biology of Cyprinus carpio from Keenjhar Lake, District Thatta Sindh, Pakistan
}

\author{
Naeem Tariq Narejo*, Parvaiz Khan, Shaista Jalbani and Rafat Rahim \\ Department of Freshwater Biology and Fisheries, University of Sindh, Jamshoro-Pakistan \\ *Corresponding author's email: $\underline{\text { dr_ntnarejo46@yahoo.com }}$ \\ Citation \\ Naeem Tariq Narejo*, Parvaiz Khan, Shaista Jalbani and Rafat Rahim. Feeding Biology of Cyprinus carpio from \\ Keenjhar Lake, District Thatta Sindh, Pakistan. Pure and Applied Biology. Vol. 5, Issue 4, pp788-792. \\ http://dx.doi.org/10.19045/bspab.2016.50099
}

\begin{tabular}{llll}
\hline \hline Received: 12/04/2016 & Revised: 13/07/2016 & Accepted: 25/07/2016 & Online First: 08/08/2016 \\
\hline
\end{tabular}

\section{Abstract}

Feeding biology of Cyprinus carpio (Lin.) was explored from Keenjhar Lake District Thatta, Sindh, Pakistan. In total 110 samples were accessed at different length groups during March August 2015. The range of sample was between 5.1 to $70.0 \mathrm{~cm}$ and $8.1-2990.4 \mathrm{~g}$ in total length and weight respectively. Results of the present study revealed that the feeding habit of Cyprinus carpio was found to be omnivorous with high feeding preference of invertebrates $(61.63 \%)$ followed by plant matter $(30.0 \%)$ and $3^{\text {rd }}$ preferred food was debris $(9.0 \%)$.It was also noted that the feeding activity of the fish was found to be increased with the increase in size.

Keywords: Feeding biology; Keenjhar Lake; Omnivorous; Invertebrates

\section{Introduction}

Food and feeding habit of fish are important biological factors for selecting a group of fish for culture in ponds to avoid competition for food among them and live in association to utilize all the available foods [1].The determination of food and feeding habit in fish is vital need for commercial production. It varies with season, size, ecological factors and the food composition in aquatic habitat also varies throughout the year [2].Knowledge on the food and feeding habit of fishes provide keys for the selection of culturable species and the importance of such information is necessary for successful fish farming. The experimental fish, Cyprinus carpio belongs to the order Cypriniformes of the family Cyprinidae. The family Cyprinidae is one of the most important families of carp fish which is widely distributed throughout the world found almost every type of water small streams, rivers, lakes, ponds and pools [3]. Common carp Cyprinus carpio are among the most successful cultured finfish species in the world because of their fast growth rate. Studies on the food and feeding habit of different fishes have been made by many workers like [4-13] but no literature is available on food and feeding habit of Cyprinus carpio from Keenjhar Lake District, Thatta, Sindh, Pakistan.

\section{Materials and methods}

110 fish specimens were collected and preserved in $10 \%$ formalin in polythene bags. Preserved fishes were then taken out, measured, the body cavity was carefully opened and gut fullness was assessed on a scale of 0 (empty) to 4 (full). The point 
method was used as described by [14, 15].The volume of stomach content as estimated by eye observation was record on an absolute scale and points were allotted to each stomach according to the volume of its contents The preserved stomach (gizzard)from each fish were dissected and the material containing plankton were analyzed by using a Sedgewik-Rafter Counting Cell (model 550, Fisons), following the standard methods [16] for counting plankton, which was identified up to genus level through different keys. The gut contents from the anterior portion of the gut that is stomach were carefully washed into a Petri dish and observed under a light microscope (Olympus, model B-2000) by using Sedgwick-Rafter counting Cell Analysis was followed by the method of [17]

Ivlev's index, Electivity (E) was calculated according to following formulae:

$$
\mathbf{E}=\frac{\mathbf{r}_{1}-\mathbf{P}_{1}}{-\mathbf{r}_{1}+\mathbf{P}_{1}}
$$

Where $r_{1}$ is the relative contents of any items in the ration, expressed, as a percentage of total numbers in the ration and $\mathrm{P}_{1}$ is the relative proportion of the same items in the environment.

The resultant values of electivity from +1 to -1 , positive values indicating selection for certain food items, negative values indicating avoidance

\section{Results}

Feeding biology of Cyprinus carpio were studied with respect to quality and quantity of food items eaten, size and pattern of feeding in relationship to total length stomach weight. The food groups recorded in the gut contents of the fishes were Invertebrates, Debris, Cholorophyceae, Bacillariophycea, Myxophyceae and Miscellaneous. Among \% of food items invertebrates $(61.0 \%)$ was the most dominant food items found in the stomach of the fish by percentage of total points followed by plant matter $(30.0 \%)$ and least observed food was debris (9.0\%) from stomach of Cyprinus carpio, the percentages of food items and their categories are shown in (Table1and 2) respectively. It was observed that Cyprinus carpio is mainly invertebrate feeder at every length group with a pronounced tendency found to be invertebrate feeder $(60.0 \%)$. It was also noted that the feeding activity of the fish was found to be increased with the increase in size. The standard length and stomach weight ratio were calculated and presented in (Table 3) which indicated that the ratio of stomach weight and standard length increased with increase of fish in size. 
Table 1. Percentage (\%) of food item observed from stomach of Cyprinus carpio from

Keenjhar Lake, District Thatta Sindh, Pakistan

\begin{tabular}{|l|l|l|l|l|l|l|l|l|l|}
\hline $\begin{array}{l}\text { Length } \\
\text { group } \\
\text { (cm) }\end{array}$ & $\begin{array}{l}\text { Rotifera } \\
\mathbf{\%}\end{array}$ & $\begin{array}{l}\text { Annelida } \\
\mathbf{\%}\end{array}$ & $\begin{array}{l}\text { Porifera } \\
\mathbf{\%}\end{array}$ & $\begin{array}{l}\text { Mollusca } \\
\mathbf{\%}\end{array}$ & $\begin{array}{l}\text { Chlro } \\
\mathbf{\%}\end{array}$ & $\begin{array}{l}\text { Bascillario } \\
\mathbf{\%}\end{array}$ & $\begin{array}{l}\text { Myxo } \\
\boldsymbol{\%}\end{array}$ & $\begin{array}{l}\text { Decay } \\
\text { \% }\end{array}$ & $\begin{array}{l}\text { Miscellaneous } \\
\boldsymbol{\%}\end{array}$ \\
\hline $15.1-20.0$ & 28.8 & 32.8 & 10.5 & 8.5 & 7.0 & 6.5 & 5.5 & 5.0 & 5.0 \\
\hline $20.1-25.0$ & 25.4 & 28.30 & 8.1 & 8.2 & 6.11 & 6.3 & 6.2 & 4.2 & 5.2 \\
\hline $25.1-30.0$ & 24.4 & 26.10 & 8.0 & 8.7 & 5.4 & 7.2 & 5.7 & 2.1 & 10.9 \\
\hline $30.1-35.0$ & 20.60 & 27.02 & 8.60 & - & 6.5 & 9.18 & 8.15 & 9.34 & 10.2 \\
\hline $35.1-40.0$ & 13.8 & 30.68 & - & 1.22 & 10.71 & 10.28 & 11.79 & 8.42 & 14.34 \\
\hline $40.1-45.0$ & - & 34.66 & 10.21 & 5.17 & 11.04 & 12.10 & 8.21 & 9.14 & 15.21 \\
\hline $45.1-50.0$ & - & 39.0 & 10.04 & 6.17 & 11.03 & 12.20 & 8.13 & 10.21 & 4.22 \\
\hline $50.1-55.0$ & 7.03 & 32.13 & 9.2 & 6.52 & 10.25 & 11.05 & 7.29 & 12.66 & 2.87 \\
\hline $55.1-60.0$ & - & 35.04 & 1.67 & 10.68 & 14.03 & 13.0 & 8.29 & 13.04 & 4.25 \\
\hline $60.1-65.0$ & 8.00 & 36.24 & 2.12 & 8.32 & 12.03 & 10.20 & 8.04 & 11.05 & 4.00 \\
\hline $65.1-70.0$ & - & 36.91 & - & 9.00 & 17.00 & 9.39 & 9.24 & 10.27 & 8.19 \\
\hline
\end{tabular}

Table 2. Categories of food item (\%) observed from stomach of Cyprinus carpio from Keenjhar Lake, District Thatta Sindh, Pakistan

\begin{tabular}{|l|c|c|c|c|}
\hline $\begin{array}{l}\text { Length group } \\
(\mathbf{c m})\end{array}$ & $\begin{array}{l}\text { Invertebrates } \\
\mathbf{\%}\end{array}$ & $\begin{array}{l}\text { Plant matter } \\
\mathbf{\%}\end{array}$ & $\begin{array}{l}\text { Decay organic matter } \\
\mathbf{\%}\end{array}$ & $\begin{array}{l}\text { Miscellaneous } \\
\text { \% }\end{array}$ \\
\hline $15.1-20.0$ & 69.3 & 19.0 & 8.0 & 3.0 \\
\hline $20.1-25.0$ & 69.9 & 18.61 & 8.0 & 2.0 \\
\hline $25.1-30.0$ & 67.2 & 20.3 & 9.2 & 3.3 \\
\hline $30.1-35.0$ & 56.4 & 23.8 & 9.3 & 10.2 \\
\hline $35.1-40.0$ & 54.4 & 22.7 & 13.4 & 9.5 \\
\hline $40.1-45.0$ & 56.0 & 21.3 & 13.1 & 4.2 \\
\hline $45.1-50.0$ & 64.2 & 21.3 & 10.3 & 4.1 \\
\hline $50.1-55.0$ & 62.8 & 20.5 & 12.6 & 4.2 \\
\hline $55.1-60.0$ & 57.3 & 25.3 & 13.2 & 4.2 \\
\hline $60.1-65.0$ & 64.6 & 20.2 & 11.0 & 8.3 \\
\hline $65.1-70.0$ & 55.9 & 25.6 & 10.2 & \\
\hline
\end{tabular}

Table 3. Relationship of stomach weight, gape of mouth with total length of Cyprinus carpio from Keenjhar Lake District Thatta Sindh, Pakistan

\begin{tabular}{|c|c|c|c|}
\hline Length group & Total length $(\mathbf{c m})$ & Stomach weight $(\mathbf{g})$ & Gape of mouth $(\mathbf{c m})$ \\
\hline $15.1-20.0$ & 14.1 & 1.0 & 1.5 \\
\hline $20.1-25.0$ & 18.0 & 1.5 & 1.5 \\
\hline $25.1-30.0$ & 24.6 & 1.5 & 1.6 \\
\hline $30.1-35.0$ & 26.0 & 1.6 & 1.7 \\
\hline $35.1-40.0$ & 32.02 & 3.3 & 2.0 \\
\hline $40.1-45.0$ & 38.43 & 3.2 & 2.5 \\
\hline $45.1-50.0$ & 43.0 & 3.5 & 3.0 \\
\hline $50.1-55.0$ & 48.48 & 5.16 & 3.12 \\
\hline $55.1-60.0$ & 51.0 & 6.5 & 3.85 \\
\hline $60.1-65.0$ & 60.0 & 8.7 & 4.0 \\
\hline $65.1-70.0$ & 65.5 & 8.9 & 4.5 \\
\hline
\end{tabular}




\section{Discussion}

The present investigation on feeding biology of Cyprinus carpio from Keenjhar Lake District Thatta was enumerated and found that Cyprinus carpio is mostly omnivorous in feeding habit. The food of Cyprinus carpio was classified into 4 groups. Among the food items it was observed that Cyprinus carpio is mainly invertebrate feeder at every length group with high preference of invertebrates (60.0\%) followed by plant matter $(30.0 \%)$ and $3^{\text {rd }}$ preference was found to be debris $(9.0 \%)$. [18, 19] reported similar observation in C. carpio from Bangladesh. The phytoplankton population recorded from the gut contents of C. carpio was under 3 groups (viz., Cholorophyceae, Cyanophyceae, Bacillariophyceae) and the zooplankton under 1 group (Rotifer) Bacillariophyceae and Chlorophyceae were the dominant phytoplankton group while Rotifer was the dominant zooplankton group in the present study that also revealed by various authors in different fish species like [11] sorted out gut of Tenualosa ilisha and observed the avoidance of zooplankton and strongly selected some genera of phytoplankton such as Bacillariophyceae, Cyanophyceae, and Chlorophyceae. [1] studied feeding habit of Gudusia chapra and determined that the G. chapra is mainly detritivorus feeder and $2^{\text {nd }}$ preference was zooplankton and also some genera of phytoplankton. [20] assessed food ingredients of $C$. carpio and exposed debris and detritus (22.00\%), zooplankton (19.69\%), aquatic plant parts (20.12\%), phytoplankton $(16.46 \%)$, semi-digested materials (14.83\%) and insects (6.78\%) as the feed items noticed in gut of fish. Above findings are in support of the present study.

\section{Conclusion}

Feed analysis of Gulfam, Cyprinus carpio (lin.) was tallied. In total 110 samples were accessed at different length group during March - August 2015 ranged between 15.1 to $70.0 \mathrm{~cm}$ from Keenjhar Lake District Thatta, Sindh, Pakistan. Results on the feeding behavior $C$. carpio was found to be omnivorous with higher preferences of invertebrates $(60.0 \%)$ followed by plant matter $(30.0 \%)$ and $3^{\text {rd }}$ preferred food was debris $(9.0 \%)$.

\section{Authors' contributions}

Conceived and designed the experiments: NT Narejo, Performed the experiments: P Khan, Analyzed the data: S Jalbani, Contributed reagents/ materials/ analysis tools: UoS Jamshoro, Wrote the paper: NT Narejo.

\section{References}

1. Narejo NT (2006). Study on the food and feeding habit of Palri, Gudusia chapra (Hamilton) from fishpond in Distt: Thatta, Sindh, Pakistan. Pakistan J Zool 38(2): 93-98.

2. Hynes HBN (1950). The food of freshwater sticklebacks (Gasterosteus aculeatus and Pygosteus pungitius) with a review of methods used in studies of the food of fishes. J Anim Ecol 19: 26-28.

3. Karim MA\& and Hossain A (1972). Studies on the biology of Mastacembelus pancalus (spiny eel) in artificial pond. Part -II. Sexual maturity and fecundity. Bangladesh J Biol and Agril Sci 1(2): 1518.

4. Doha S (1974). Investigation into the biology of the goby Glossogobius giuris (Ham.-Buch.) (Perciformes: Gobidae). Bangladesh J. Zool. 2(2): 95-106.

5. Dewan S \& Saha SN (1979).Food and feeding habits of Tilapia nilotica (L.) (Perciformes: Cichlidae). II. Dial and Seasonal patterns of feeding. Bangladesh J Zool 7(2): 75-80

6. Jhingran A G (1972). Diet composition of Gudusia chapra (Ham) from the Ganga River System. Proc Indian Natr Sci Acad (B)38: 94-105

7. Bhuiyan A S \& Haque MS (1984). Studies on the seasonal changes of food habit of Mystus vittatus (Bloch) 
(Bagridae: Cypriniformes). Proc 4th Nat Zool Conf Bangladesh 88-91.

8. Bhuiyan, AS\& Islam MN (1991). Observations on the food and feeding habit of Ompok pabda (Ham.) from the river Padma (Siluridae: Cypriniformes). Pakistan J Zool 23(1): 75-77.

9. Hossain MA Rahman MH \& Parween S (1991). Notes on the length-weight relationship of Lepidocephalus guntea. Bangladesh J Zool 19(1): 145-146.

10. Bhuiyan AS, Nessa Q\& Begum M (1998). The food and feeding habit of Puntius gonionotus (Bleeker) (Cyprinidae: Cypriniformes). Bangladesh J Zool, 26(1): 73-78.Narejo NT, Laghari SM \& 11.

11. Narejo NT Laghari SM \& SIH Jafri (2005). Food and feeding habit of palla, Tenualosa ilisha (Hamilton) from ring dam (up-stream) River Indus. Pakistan $J$ Zool 37(4): 265-267.

12. Lashari PK Narejo NT \& Laghari YM (2010).Feeding behavior of a carp, Cirrhinus reba (Hamilton) from fishponds of District Jacobabad, Sindh, Pakistan. Pakistan J Zool 42(3): 345348

13. Hashim F, Narejo NT Jalbani S \& Jalbani YM. (2014). Studies on the feeding behavior of a carp, Labeo gonius (Hamilton) from Keenjhar Lake,
District Thatta, Sindh Pakistan. Standard Research Journal and essays 2(9):418-420.

14. Mian JU\& Dewan S (1977). Bangladesh J agric Sci 4: 81-88.

15. Dewan S \& Shaha SN (1979). Food and feeding habits of Tilapia nilotica (L.) (Perciformes:Cichlidae). II. Diel and seasonal patterns of feeding. Bangladesh J Zool 7(2): 75-80.

16. Alpha (1985) American Public Health Association

17. Ivlev VS (1961). Experimental ecology of the feeding of fishes Yale University Press, New Heaven Connecticut, USA.

18. Berthou EG (2002). Ontogenetic Diet Shifts and Interrupted Piscivory in Introduced Largemouth Bass (Micropterus salmoides). Internat Rev Hydrobiol 8720024 353-363.

19. Rahman MM, Rehman MMM, Nahar DA, AhmedFM, Sarker A, Subba BR Hossain MY (2013). Diet and feeding habits of Cyprinus carpio in relation with water quality of integrated ricefish farming ecosystem. Our Nature 11(2):138-151

20. Manon MR \& Hossain MD (2011). Habit of food and feeding Cyprinus carpio var. specularis. $J \quad S c i$ Foundation 9(1\&2): 163-181. 